\title{
PENGENALAN DAN SOSIALISASI PENERAPAN INSTALASI KELISTRIKAN SWER UNTUK PENERANGAN JALAN DI BANJAR SAMBIAN UNDAGI DESA TIMPAG, KECAMATAN KERAMBITAN, TABANAN
}

\author{
I W Rinas ${ }^{1}$, I M Suartika ${ }^{2}$, A I Weking ${ }^{3}$, dan A A G Maharta Pemayun ${ }^{4}$
}

\begin{abstract}
ABSTRAK
Banjar adat Sambian Undagi yang mempunyai anggota 70 KK merupakan bagian dari krama Desa Adat Sambian dan termasuk wilayah Desa Dinas Desa Timpag Kerambitan Tabanan. Karena letaknya tidak di jalur jalan raya sampai saat ini belum mendapatkan fasilitas penerangan jalan dari Pemerintah. Untuk penerangan jalan masyarakat sendiri memasang penerangan jalan dengan menyambungkan daya listrik dari balai banjar. Penyambungan membutuhkan penghantar yang panjang. Untuk penghematan penghantar akan diterapkan metode SWER. Metode SWER (Single wire earth return) hanya memerlukan satu kabel untuk menyalurkan daya listrik sehingga bisa mengurangi biaya untuk kabel ini menjadi setengahnya. Dengan grounding yang baik dan memakai stabilizer, kualitas daya listrik pada ujung SWER akan terjaga dan tetap stabil sesuai standar.
\end{abstract}

Kata kunci : SWER, Penerangan Jalan, Puil 2011

\section{PENDAHULUAN}

\subsection{Analisis Situasi}

Banjar adat Sambian Undagi yang mempunyai anggota $70 \mathrm{KK}$ termasuk wilayah Desa Dinas Desa Timpag kerambitan Tabanan. Karena letaknya tidak di jalur jalan raya sampai saat ini belum mendapatkan fasilitas penerangan jalan dari Pemerintah. Untuk penerangan jalan masyarakat sendiri memasang penerangan jalan dengan menyambungkan daya listrik dari balai banjar. Penyambungan membutuhkan penghantar yang panjang. Untuk penghematan penghantar akan diterapkan metode SWER. Metode SWER (Single wire earth return) hanya memerlukan satu kabel untuk menyalurkan daya listrik sehingga bisa mengurangi biaya untuk kabel ini menjadi setengahnya. Dengan sistem pembumian yang baik dan memakai stabilizer, kualitas daya listrik pada ujung SWER akan terjaga dan tetap stabil sesuai standar [1], [2], [3], [4].

\footnotetext{
${ }^{1}$ Program Studi Teknik Elektro, Fakultas Teknik, Universitas Udayana, Kampus Bukit Jimbaran, Indonesia, rinas@unud.ac.id

${ }_{2}^{2}$ Program Studi Teknik Elektro, Fakultas Teknik, Universitas Udayana, Kampus Bukit Jimbaran, Indonesia

${ }^{3}$ Program Studi Teknik Elektro, Fakultas Teknik, Universitas Udayana, Kampus Bukit Jimbaran, Indonesia

${ }^{4}$ Program Studi Teknik Elektro, Fakultas Teknik, Universitas Udayana, Kampus Bukit Jimbaran, Indonesia
} 


\subsection{Rumusan Masalah}

Bagaimana memberikan pengenalan tentang konsep SWER dan bagaimana cara pemasangan instalasi SWER kepada anggota Banjar sehingga instalasi penerangan jalan dapat dipasang dengan biaya yang lebih murah.

\subsection{Tujuan Kegiatan}

Kegiatan ini bertujuan untuk memperkenalkan dan mensosialisasikan konsep SWER dan memberikan cara pemasangan instalasi kelistrikan SWER kepada anggota Banjar sehingga instalasi penerangan jalan dapat dilakukan.

\subsection{Manfaat Kegiatan}

Manfaat Pengabdian Masyarakat ini bagi masyarakat Desa Pekutatan adalah telah dipasangnya sistem pengaman listrik (sesuai PUIL 2011), sehingga bila terjadi kesalahan pada instalasi maupun peralatan listrik yang dipergunakan pengaman dapat beroperasi dengan baik (sehingga tidak terjadi bahaya akibat listrik/kebakaran). Manfaat bagi Fakultas Teknik, adalah menambah wawasan tim fakultas teknik untuk mengaplikasikan ilmunya.

\section{METODE PEMECAHAN MASALAH}

Tim Pengabdian Kepada Masyarakat melakukan kegiatan sebagai berikut :

1. Memberikan ceramah kepada anggota subak konsep instalasi kelistrikan SWER serta keunggulankeunggulannya

2. Mengadakan peragaan atau demo cara pemasangan instalasi kelistrikan SWER sehingga anggota subak bisa menyaksikannya secara langsung

3. Memberikan satu paket instalasi SWER

4. Mengadakan diskusi dan tanya jawab tentang segala aspek dan prospek SWER.

5. Memberikan ceramah kepada masyarakat konsep instalasi kelistrikan yang baik dan benar sesuai PUIL 2011

6. Melakukan evaluasi ke desa hasil sosialisasi yang telah dilakukan.

\section{HASIL DAN PEMBAHASAN}

\subsection{Realisasi Pemecahan Masalah}

Untuk memberikan ketersediaan tenaga listrik kepada anggota Banjar Sambian Undagi akan diadakan ceramah dan demo tentang instalasi kelistrikan SWER. Sifat dari sistem kelistrikan SWER ini adalah hanya membutuhkan satu kabel karena grounding kembalinya melalui tanah (earth).

Realisasi dari pemecahan masalah di atas adalah dengan pemasangan instalasi listrik satu fasa pada balai subak yang berlokasi di Banjar Sambian Undagi. Kegiatan pertama adalah menarik kabel satu fasa dari tiang terdekat dengan balai subak ke balai subak sendiri. Instalasi kelistrikan yang dipasang pada balai subak meliputi satu buah lampu penerangan dengan saklarnya, satu buah stop kontak dan satu buah arde untuk pentanahan. Lampu penerangan sudah bisa menyala dengan baik dengan tegangan pada stop kontak sebesar 220 Volt. Pentanahan atau grounding mempunyai tahanan sebesar $2 \mathrm{Ohm}$ dimana sesuai dengan persyaratan pentanahan untuk sistem SWER maksimal $10 \mathrm{Ohm}$. 


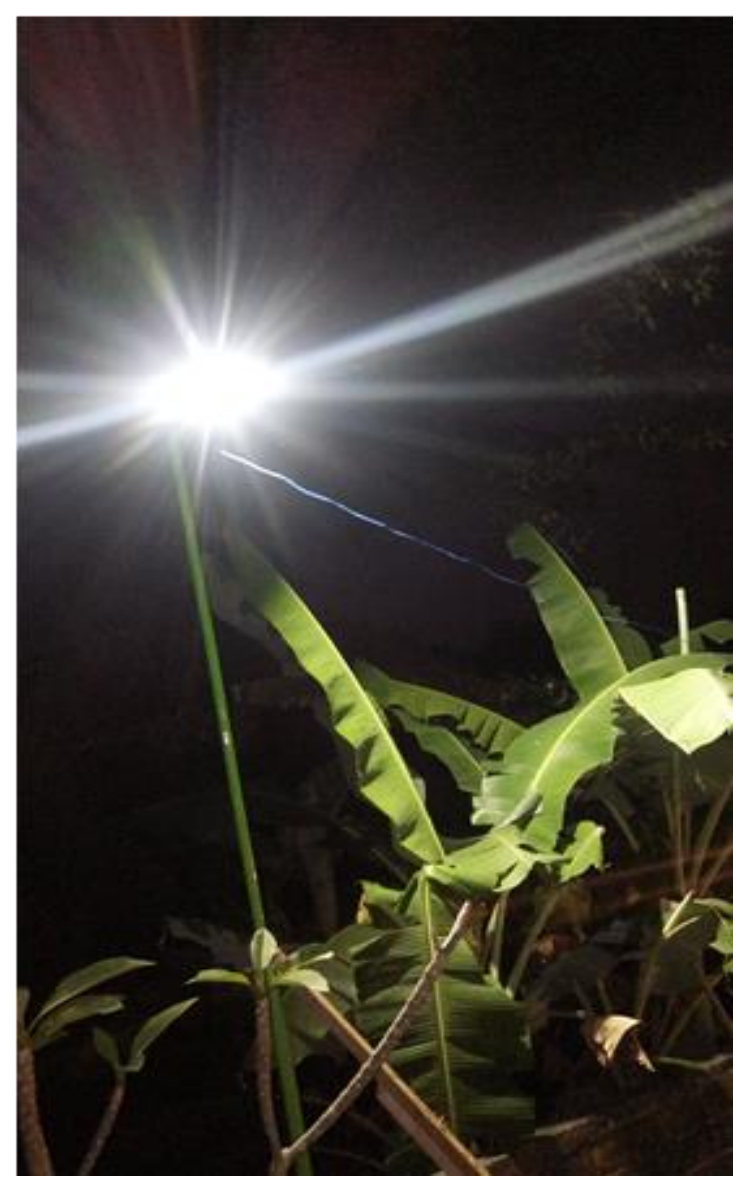

Gambar 4.1 Foto Hasil Pemasangan Instalasi SWER

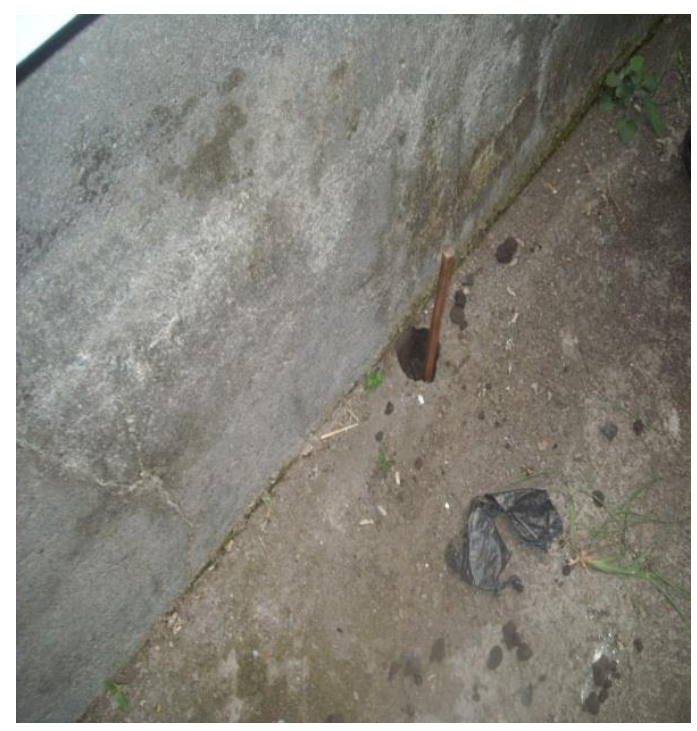

Gambar 4.2 Foto Kegiatan Pemasangan Pembumian 


\subsection{Hasil Pelaksanaan Kegiatan}

1. Beberapa masyarakat mampu dan memahami memasang instalasi penerangan luar dengan sistem SWER yang dipasang di Jalan seperti gambar di atas.

2. Masyarakat mengetahui pemeliharaan instalasi listrik yang benar dan memahami umur instalasi yang sesuai standar.

3. Masyarakat mampu melakukan penghematan energi listrik

4. Masyarakat diberikan pemahaman batasan-batasan dan jenis-jenis kabel yang boleh dipergunakan.

\section{KESIMPULAN}

1. Masyarakat sudah mendapatkan sosialisasi dalam bentuk ceramah dan menyaksikan demontrasi dengan pemasangan penerangan jalan dengan instalasi SWER

2. Masyarakat ikut serta memasang instalasi luar yang dipasang di sepanjang jalan Banjar Undagi Timpag, Kerambitan - Tabanan.

\section{DAFTAR PUSTAKA}

------, 2011. Persyaratan Umum Instalasi Listrik ( PUIL 2011). Jakarta

Budiman, M. Dkk. 2000. Panduan Instalasi Listrik Untuk Rumah Berdasarkan PUIL 2000. Jakarta : Yayasan Usaha Penunjang Tenaga Listrik Bekerja sama dengan Copper Development Centre. South East Asia. Handoko, P. 2000. Pemasangan Instalasi Listrik Dasar. Yogyakarta : Kanisius.

Harten, PV. Terjemahan : Setiawan E. 1991. Instalasi Listrik Arus Kuat 1. Bandung : Bina Cipta. Harten, PV. Terjemahan : Setiawan E. 1991. Instalasi Listrik Arus Kuat 2. Bandung : Bina Cipta. Harten, PV. Terjemahan : Setiawan E. 1991. Instalasi Listrik Arus Kuat 3. Bandung : Bina Cipta. 